\title{
Antioxidant Activity of Bioactive Protein of Kerang Kepah (Atactodea striata) from South Sulawesi
}

\author{
Tahirah Hasan ${ }^{1}$, Abdul Wahid Wahab ${ }^{1}$, Natsir Djide ${ }^{2}$, Muhammad Zakir ${ }^{1, ~ *}$ \\ ${ }^{1}$ Department of Chemistry, Graduate School of Science, Hasanuddin University, Makassar 90245, South Sulawesi, Indonesia \\ ${ }^{2}$ Faculty of Pharmacy, Hasanuddin University, Makassar 90245, South Sulawesi, Indonesia
}

\section{Email address:}

tahirahhasan@yahoo.com (T. Hasan),wahidwahab@yahoo.com (A. W. Wahab), natsirjide@yahoo.com (N. Djide), muhammadzakir@gmail.com (M. Zakir)

\section{To cite this article:}

Tahirah Hasan, Abdul Wahid Wahab, Natsir Djide, Muhammad Zakir. Antioxidant Activity of Bioactive Protein of Kerang Kepah (Atactodea striata) from South Sulawesi. American Journal of Biomedical and Life Sciences. Vol. 3, No. 6, 2015, pp. 111-114.

doi: 10.11648/j.ajbls.20150306.12

\begin{abstract}
Antioxidant activity test on protein extract of Kerang Kepah (Atactodea striata) by scavenging method of free radical of DPPH (N, N-diphenyl-N-picrylhydrazyl) has been carried out. This study was conducted to determine the antioxidant activity and the amino acid composition of the protein extract of Atactodea striata. The analysis results showed that the protein extract of Atactodea striata has the most complete amino acid composition and the highest antioxidant activity of the protein fraction at a rate of $30-50 \%$ ammonium sulfate saturation with IC50 value of $183.75 \mu \mathrm{g} / \mathrm{mL}$. However, when it is compared to the antioxidant activity of ascorbic acid (IC50 values $=2.51 \mu \mathrm{g} / \mathrm{mL}$ ), the antioxidant activity of the protein extract fraction of Atactodea striata is still much lower.
\end{abstract}

Keywords: Atactodea striata, Antioxidant, DPPH, HPLC

\section{Introduction}

Consumption of sea shells as a popular sea food in the last few decades is increasing. High diversity of marine organisms, including sea shells, is a pillar of traditional knowledge of the various drugs. Molluskis a marine commodity which is a potential source of bioactive compounds as candidates for various purposes. Bivalve and gastropod mollusc groups whose existence is quite abundant in the tropical waters as a source of animal protein hasa relatively cheap prices. Bioactive compounds found in mollusks which are identified as peptide, dipeptida, sesquiterpenes, squalene, terpenes, alkaloids, polipropionate, nitrogen compounds, fatty acid derivatives, makrolide and other compounds have a specific bioactivity $[1,2,3]$.

Several studies have been conducted on the bioactive compounds of molluscs, especially bivalves and gastropods that is potential as a nutraceutical or pharmaceutical. Some of them are marine leeches Discodoris sp. [5], snails IpongIpong Salmo fascilaria [6], Cyclina sinensis [7], abalone Haliotis discus hannai Ino [8], and green mussels Perna viridis Linn [9].

Natural products isolated from bivalves and gastropods

* Muhammad Zakir: Corresponding author have been used, among others, as an antioxidant, antitumor, antiviral, antibacterial, antifungal, anticancer, cytotoxic and enzyme inhibitor [8, 9]. However, it is still lack a report so far on the antioxidant activity of the protein metabolites isolated from the class of bivalves.

This study was conducted to isolate the bioactive proteins of Kerang Kepah (Atactodea striata) fromwaters of Laiya Island, Pangkep, South Sulawesi. Active compounds obtained will be tested on their activity as an antioxidant. The results of this study will be developed and applied in the biotechnology industry for further utilization in the formal health care system. This study is also important in the exploration of active compounds as antioxidants in other marine resources.

One of marine organismas that attracts attention is Kerang Kepah (Atactodea striata). This type of shell fish is a food that favored people since long time ago, and even the shell is used as traditional medicine for a variety of chronic diseases, especially for hepatitis. Therefore, Atactodea striatais suspected to contain of bioactive compounds (primary and secondary metabolites) because traditionally it has been used as medicine.

Several researches indicates that some species of mollusc has a protein content so that they continue to grow and 
develop properly at sea where a lot of bacteria and other predators around them. The protein content of marine organism can act as an agent for reducing free radicals, chelating metal ions, trapping free radicals, and can inhibit some types of bacteria. However, there is still less research data on protein compounds as raw material medicines. Meanwhile, the protein has several advantages as a very promising material for antimicrobial drugs and anticancer acceptable without any side effects; so that researchers began to develop a treatment or therapy of disease by using a protein compound [10].

Based on the above cases, this research is conducted to assess the active protein compound of marine shells from Laiya Island Pangkep, South Sulawesi. The purpose of this research is to determine the antioxidant activity and the amino acid composition of protein extracts of Kepah (Atactodea striata). The result of this research is expected to reveal the potential of sea shells as a producer of compounds that have antioxidant activity.

\section{Methods}

\subsection{Sample Preparation}

Samples were taken in coastal waters of Laiya Island Pangkep, South Sulawesi. Samples were cleaned form dirt, released from the shell, and weighed $500 \mathrm{~g}$ and then milled using a blender by adding Tris- $\mathrm{HCl}$ buffer $0.1 \mathrm{M} \mathrm{pH} 8.3$ and then stored in a $4^{\circ} \mathrm{C}$ refrigerator overnight, and finally filtered with a Buchner funnel. The filtrate obtained is freezed and then melted 2-3 times, centrifuged at $6000 \mathrm{rpm}$ at $4^{\circ} \mathrm{C}$ for $30 \mathrm{~min}$, and finally the supernatant is stored in the refrigerator before continuing trials of antioxidant activity.

\subsection{Fractionation with Ammonium Sulfate}

Crude protein extract is further isolated by ammonium sulfate fractionation. The saturation level $(0-90 \%)$ based on the method of Bollag and Edelstein [11]. The resulting protein precipitate is dissolved in a solution of Tris- $\mathrm{HCl}$ buffer $\mathrm{pH} 8.3$, and followed by dialysis using selophan bag (Sigma).

\subsection{Dialysis}

Dialysis was performed using a cellophane membrane (Sigma D 0655). According to Plummer [12], deposition and fractionation results of each level of saturation of ammonium sulfate is dialyzed in a $0.1 \mathrm{M}$ Tris- $\mathrm{HCl} \mathrm{pH} 8.3$, then dialyzed with Tris- $\mathrm{HCl}$ buffer $\mathrm{pH} 8.30 .01 \mathrm{M}$. Dialysis continued until the buffer solution is colorless. Protein content of dialysate was tested as well as antibacterial and antioxidant activity.

\subsection{Determination of Protein and Amino Acid Composition}

Determination of protein levels were calculated using a Bio-rad. In Eppendorf tube, it is inserted $4 \mu \mathrm{L}$ of sample solution and added $746 \mu \mathrm{L}$ and $200 \mu \mathrm{L} \mathrm{dH}_{2} \mathrm{O}$.Bio-radprotein assay was homogenized and allowed to stand for 30 minutes. Absorbance is measured at the maximum wavelength.
Determination of protein concentration is carried out using linear regression equation and the amino acid composition through HPLC method.

\subsection{Antioxidant Activity Test Method Immersion Effect Against Free Radical DPPH}

Antioxidant activity test was conducted by soaking effect on DPPH free radicals. Antioxidant compounds tested its effectiveness in reducing the DPPH free radical activity. Protein extracts made some concentration (ppm), respectively included in $5 \mathrm{~mL}$ volumetric flask, add $1.0 \mathrm{~mL}$ into each $0.1 \mathrm{mM}$ DPPH solution and the volume was made up to the mark, then incubated at $37^{\circ} \mathrm{C}$ for $30 \mathrm{~min}$ and the absorbance was measured at a wavelength of $517 \mathrm{~nm}$. Ascorbic acid is used as a comparison.

\section{Results and Discussions}

Kepah Samples (Atactodea striata) obtained from coastal waters of Laiya Island, Pangkep Regency, South-Sulawesi. Meat samples of Atactodea striata was extracted using Tris$\mathrm{HCl}$ buffer $0.1 \mathrm{M} \mathrm{pH} 8.3$ and then stored in a $4^{\circ} \mathrm{C}$ refrigerator overnight and filtered with a Buchner funnel. The filtrate obtained was frozen and melted 2-3 times and then centrifuged at $6000 \mathrm{rpm}$ at $4^{\circ} \mathrm{C}$ for 30 minutes. Crude extract in protein isolation results was further fractionated with ammonium sulfate with the saturation level (0-90\%) based on the method of Bollag and Edelstein [11]. The resulting protein precipitate was dissolved in a solution of Tris- $\mathrm{HCl}$ buffer $\mathrm{pH} 8.3$, followed by dialysis using selophan bag (Sigma D 0655).

According to Plummer [12], precipitation of fractionation results of each level of ammonium sulfate saturation is dialyzed in a $0.1 \mathrm{M}$ Tris- $\mathrm{HCl} \mathrm{pH} 8.3$, and further dialyzed with Tris- $\mathrm{HCl}$ buffer $\mathrm{pH} 8.30 .01 \mathrm{M}$. Dialysis is continued until the buffer solution is colorless. Dialysate obtained was tested for protein content and antioxidant activity.

Determination of protein levels were calculated using a Biorad. Eppendorf tube inserted into a $4 \mu \mathrm{L}$ sample solution was added $746 \mu \mathrm{L}$ and $200 \mathrm{~mL}$ dH2O Bio-rad protein assay was homogenized and allowed to stand for 30 minutes. Absorbance is measured at the maximum wavelength. Determination of protein content is carried out using a linear regression equation. Measurement results of protein content of Kepah (Atactodea striata) using Bio-rad can be seen in Table 1.

Tabel 1. The protein concentration of the fractionation of various levels of ammonium sulfate saturation of Kepah extract (Atactodea striata).

\begin{tabular}{lllll}
\hline No & $\begin{array}{l}\text { Protein } \\
\text { fraction }\end{array}$ & $\begin{array}{l}\text { Fraction } \\
\text { volume }(\mathbf{m L})\end{array}$ & $\begin{array}{l}\text { Protein } \\
\text { concentration } \\
(\mathbf{m g} / \mathbf{m L})\end{array}$ & $\begin{array}{l}\text { Total } \\
\text { protein } \\
(\mathbf{m g})\end{array}$ \\
\hline 1 & Crude extract & 500 & 2.015 & 1.007 \\
2 & $\mathrm{~F}_{1}(30-50 \%)$ & 420 & 1.48 & 621.6 \\
3 & $\mathrm{~F}_{2}(30-50 \%)$ & 400 & 1.320 & 528 \\
4 & $\mathrm{~F}_{3}(50-70 \%)$ & 370 & 0.800 & 296 \\
5 & $\mathrm{~F}_{4}(70-90 \%)$ & 200 & 0.640 & 128 \\
\hline
\end{tabular}

The results of the analysis of protein content of Kepah 
(Atactodea striata) in Table 1 indicate that the protein concentration of the crude extract is $1,007 \mathrm{mg}$. Distribution of protein in each fractionation with ammonium sulfate at a rate of $0-90 \%$ saturation showed the highest protein concentration was found in the fraction with $30 \%$ saturation level is $621.6 \mathrm{mg}$. While the lowest protein concentration found in the fraction with $90 \%$ saturation level is $128 \mathrm{mg}$. The measurement results showed that the total protein content of each fraction proteins differ from each fraction. This suggests that the protein precipitated from each fraction is a different protein. The protein is precipitated by differences in solubility in water [13].

The results of the analysis of the amino acid composition of protein extract fraction of Kepah (Atactodea striata) by HPLC (High Performance Liquid Chromatography) can be seen in Table 2.

Table 2. Amino Acid Composition of Protein Extract Fraction Kepah (Atactodea striata) with HPLC Method.

\begin{tabular}{|c|c|c|c|c|}
\hline \multirow[b]{2}{*}{ Amino acid } & \multicolumn{4}{|c|}{ Protein extract } \\
\hline & $\begin{array}{l}F_{1}(\mathrm{mg} / \mathbf{1 0 0} \\
\mathrm{g})\end{array}$ & $\begin{array}{l}F_{2}(\mathrm{mg} / \mathbf{1 0 0} \\
\mathrm{g})\end{array}$ & $\begin{array}{l}F_{3}(\mathrm{mg} / \mathbf{1 0 0} \\
\mathrm{g})\end{array}$ & $\begin{array}{l}F_{4}(\mathrm{mg} / 100 \\
g)\end{array}$ \\
\hline L-Histidin & - & - & - & - \\
\hline L-Serin & 31.26 & 40.79 & - & 34.75 \\
\hline L-Arginin & 37.21 & 55.64 & - & - \\
\hline Glysin & 60.59 & 172.20 & 275.79 & 31.89 \\
\hline L-Asam Aspartat & 47.53 & 24.08 & - & - \\
\hline L-Asam Glutamat & 178.58 & 106.67 & - & 124.78 \\
\hline L-Treonin & 23.76 & 65.47 & - & - \\
\hline L-Alanin & 37.73 & 97.38 & - & - \\
\hline L-Prolin & 28.30 & 34.19 & - & - \\
\hline L-Sistin & - & 30.99 & - & - \\
\hline L-Lisin & 30.15 & 505.59 & - & - \\
\hline L-Tirosin & 49.02 & 208.90 & - & - \\
\hline L-Metionin & 484.23 & 245.61 & 477.93 & 350.04 \\
\hline L-Valin & 49.75 & 42.16 & - & - \\
\hline L-Isoleusin & 19.36 & 54.01 & - & - \\
\hline L-Leusin & 38.08 & 39.92 & - & - \\
\hline L-Phenilalanin & 11.60 & 65.15 & - & 72.72 \\
\hline
\end{tabular}

Antioxidant activity test was conducted using the damping effect against free radical DPPH using visible spectrophotometer at a wavelength of $517 \mathrm{~nm}$. Protein extracts was tested for its effectiveness in reducing the DPPH free radical activity. Ascorbic acid is used as a comparison. Reduction of DPPH free radical activity of each protein fraction, with a respective ammonium sulfate saturation level (\%) 0-30, 30-50, 50-70 and 70-90, can be seen in Table 3.

It is clearly seen from the antioxidant activity of each protein fraction that the percent of DPPH with the greatest antioxidant activity is found in fraction F2 with IC50 $183.75 \mu \mathrm{g} / \mathrm{mL}$, but it is still far below the antioxidant activity of ascorbic acid which has IC50 $2.51 \mu \mathrm{g} / \mathrm{mL}$. The significant difference in the antioxidant activity of each fraction is probably resulted from differences in the amino acid composition of each fraction $[14,15]$.
Table 3. Antioxidant activity of Protein Extract Fraction Kepah (Atactodea striata) with method Damping Effects Against Free Radical DPPH.

\begin{tabular}{|c|c|c|c|}
\hline Protein fraction & $M(\mu \mathrm{g} / \mathrm{mL})$ & $\%$ Inhibition & $\mathrm{IC}_{50}(\mu \mathrm{g} / \mathrm{mL})$ \\
\hline \multirow[t]{5}{*}{$F_{1}(0-30 \%)$} & 50 & 26.71 & 383.71 \\
\hline & 100 & 30,16 & \\
\hline & 150 & 33.60 & \\
\hline & 200 & 37.30 & \\
\hline & 250 & 40.74 & \\
\hline \multirow[t]{5}{*}{$F_{2}(30-50 \%)$} & 50 & 43.65 & 183.75 \\
\hline & 100 & 46.56 & \\
\hline & 150 & 47.08 & \\
\hline & 200 & 51.59 & \\
\hline & 250 & 53.17 & \\
\hline \multirow[t]{5}{*}{$\mathrm{F}_{3}(50-70 \%)$} & 50 & 16,40 & 906,05 \\
\hline & 100 & 19,31 & \\
\hline & 150 & 20,11 & \\
\hline & 200 & 22,49 & \\
\hline & 250 & 24,34 & \\
\hline \multirow[t]{5}{*}{$\mathrm{F}_{4}(70-90 \%)$} & 50 & 18,62 & 688,33 \\
\hline & 100 & 21,96 & \\
\hline & 150 & 25,13 & \\
\hline & 200 & 27,25 & \\
\hline & 250 & 28,04 & \\
\hline \multirow[t]{5}{*}{ Ascorbic acid } & 5 & 54.92 & 2.51 \\
\hline & 10 & 61.66 & \\
\hline & 15 & 78.24 & \\
\hline & 20 & 83.94 & \\
\hline & 25 & 92.22 & \\
\hline
\end{tabular}

\section{Conclusions}

Based on the results of research conducted, it can be concluded that the protein extract of Kepah (Atactodea striata) at the level of $30-50 \%$ saturation of ammonium sulfate has the highest antioxidant activity against DPPH (diphenyl picrylhidrazyl) free radical reduction with IC50 value of $183.75 \mu \mathrm{g} / \mathrm{mL}$. This analysis result with DPPH free radical reduction activity showed that the protein fraction of Atactodea striata is considered as an effective antioxidant.

\section{References}

[1] J.L. Balcazar, R.Z. Blas, D. Cuningham, Vendrell and Muzquiz, The Rute of Probiotic in Aquaculture, Veterinary Microbiol. vol. 114, pp. 173-186, 2006.

[2] J.W. Blunt, B.R. Copp, M.H.G. Munro, Northcote and M.R. Prinsep, Marine Natural Products. Natural Product Reports, vol. 23, pp. 26-78, 2006.

[3] U. Grienke, J. Silke, D. Tasdemis, "Bioactive compounds from marine mussels and their effects on human health," Food Chem. Vol. 142, pp. 48-60, 2014.

[4] R.D. Barnes, Invertebrate Zoology, Saunders College, Fourth Edition, 1982.

[5] L. Nurjanah, D. Hardjito, Monintya, M. Bintang, and D.R. Agungpriyono,"Aktivitasantioksidanlintahlaut (Discodorissp) dariperairan Pulaulintahlaut dariperairan Pulau Buton Sulawesi Tenggara," Prosiding Seminar Nasional Pengolahan Produkdan Bioteknologi Kelautandan Perikanan. Jakarta, 2009. 
[6] A. Nurjanah, Abdulla, and A. Apriand, "Aktivitas antioksidan dan komponen bioaktif pada keong ipong-ipong (Fasciolaria salmo),"J. Pengolahan Hasil Perikanan Indonesia, vol.14, pp 22-29, 2011.

[7] C. Jiang, M. Wang, J. Lin, D. Gan, X. Zeng, "Extraction, preliminary characterization, antioxidant and anticancer activities in vitro of polysaccharides from Cyclinosinensis," Carbohydrate Polymers, vol 84, pp. 851-857, 2011.

[8] D.Y. Zhou, B.W. Zhu, L. Qiao, H.T. Wu, D.M. Li, J.F. Yang and Y. Murata, "In vitro antioxidant activity of enzymatic hydrolysates prepared from abalone (Haliotis discus hannaiIno) viscera," Food and Bioproducts Processing, 2011.

[9] V.N. Madhu, K. Sivaperumal, K. Kamala and B.G. Kulkarni, "Antibacterial and Antioxidant Activities of The Tissue Extract of Verna viridis From Versova Coast," International Journal of Pharmacy and Pharmaceutical Sciences, Mumbai, 2014.
[10] L. Huang, Protein dalam Air Mata Obat untuk AIDS, (On line), (http://www.rad .net.id/warta/wao4701.htm, (diakses 2 Januari 2013), 1999.

[11] Nollet, M. L. Leo, "Handbook of Food Analysis and Amino Acid," 1996.

[12] D.T. Plummer, "An Introduction to Practical Biochemistry," Second Edition. Tata Mc. Graw Hill Publishing Company Ltd. New Delhi, 1979.

[13] R.K. Scopes, "Protein Purification Principles and Ptactice," Second edition, Springger-Verlag, New York, 1987.

[14] Liyana, F. Pathiranam, Shahidi," Antioxidant activity of commercial soft and hard wheat (Triticum aestivum L.) as affected by gastric $\mathrm{pH}$ conditions," J. Agric. Food Chem. Vol. 53, pp. 2430-2440. 2005.

[15] W. Moka,"Identifikasi dan Inventarisasi Jenis Kerang Laut yang Digunakan Sebagai Obat Tradisonal di Sulawesi Selatan", UNHAS, Makassar, 1982. 